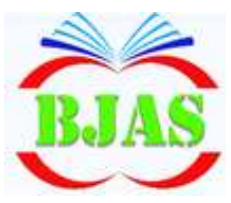

ISSN 1814 - 5868
Available online at http://bjas.bajas.edu.iq

https://doi.org/10.37077/25200860.2021.34.2.02

College of Agriculture, University of Basrah

Basrah J. Agric. Sci. 34(2), 10-28, 2021
Basrah Journal of Agricultural Sciences

E-ISSN: 2520-0860

\title{
Effect of Acid Whey, Enzymatic Whey, Magnetized and Unmagnetized Whey on the Qualitative and Productive Traits of Date Palm
}

\author{
Haider I. Ali ${ }^{1 *}$, Abdulkareem M Abed ${ }^{2} \&$ Wafaa H. Khassaf ${ }^{3}$ \\ ${ }^{1}$ Department of Food Science, College of Agriculture, University of Basrah, Iraq \\ ${ }^{2}$ Department of Horticulture, College of Agriculture, University of Basrah, Iraq \\ ${ }^{3}$ Date Palm Research Centre, University of Basrah, Iraq
}

*Corresponding author email: haiderr_2004@yahoo.com

Received 30 October 2020; Accepted 9 February 2021; Available online 30 October 2021

\begin{abstract}
This study was conducted in one of the private orchards in the district of Abu Al-Khaseeb, Basrah province during the growing seasons 2017 - 2018 in order to examine the effect of spraying acidic whey, enzymatic whey and magnetized and non-magnetized whey on date palm cultivars Phoenix dactylifera L. agricultural (yellow Shwithi and AlKhdrawi). A Concentration of $100 \%$ of the whey was applied to the fruits. The results of the study showed the superiority of the yellow Shwithi and Al-Khdrawi regarding the Qualitative and Productive characteristics. There was a significant difference between the date palm cultivars regarding the length, diameter, the weight of fruit, dry matter, total and reduced sugars and fruit content of invertase enzyme were recorded $33.45 \mathrm{~mm}, 20.89 \mathrm{~mm}$, $9.302 \mathrm{~g}, 37.685 \%, 50.28 \%, 36.09 \%$ and 2347 units $/ \mathrm{kg} / \mathrm{CO}_{2}$. The spray treatment was characterized by enzymatic whey in most of the study treatments of fruit length, fruit weight, total sugars and invertase enzyme. It reached $34.55 \mathrm{~mm}, 9.883 \mathrm{~g}, 56.15 \%$ and 2005.3 units $/ \mathrm{kg} / \mathrm{CO}_{2}$. The results also showed the importance of bilateral interaction between the variety and spray treatment.
\end{abstract}

Keyword: Date Palm, Whey protein, Magnetic field.

\section{Introduction}

The date palm Phoenix dactylifera $\mathrm{L}$. belongs to the Arecaceae family, a sub-tropical fruit tree cultivated in Iraq and some parts of the Middle East. It is originally from southern Iraq and the Arabian Gulf region, and it was classified as great economic and social importance in many countries of the world (Barreveld, 1993). Fertilization is considered one of the most important service operations for date palm. The date palm needs fertilizer like other fruit trees to get nutrients, which significantly affects the productivity of trees (Ibrahim, 2008). However, these used industrial chemicals had negative side effects on humans, the environment and living organisms. Therefore, the researchers looked for alternative sources to have the natural compounds that have a similar effect to the physical, chemical and physiological characteristics of date palm fruits (Rambabu et al, 2020). Whey proteins have many qualities that improve fruit properties and 
better productivity. The whey proteins used successfully in baking, meat products, cakes and candies. Whey proteins contribute to some properties, including their solubility (Al-Fayadh, 2009).

Many modern studies and scientific research have been concerned with the use of whey proteins in the manufacture of many different dairy products in order to raise the nutritional value and improve the textures and properties of the products, increase refinement, reduce the problems of eliminating whey and pollution of the environment. Moreover, it is a cheap source of protein compared to other sources. The whey is known as the yellowish green fluid obtained after the separation of milk thrombus with enzymatic or acidic cheese, so we find that there is a difference in the composition of the whey produced depending on the type of cheese. The whey is known as the yellowish green fluid obtained after the separation of milk thrombus with enzymatic or acidic cheese, so we find there is a difference in the composition of the whey produced depending on the type of cheese. The acidity and $\mathrm{pH}$ of acid whey and Sweet Whey were within $0.4 \%, \mathrm{pH} 5.1,0.1-0.2 \%$ and $\mathrm{pH}$ of 5.9 , respectively. Most whey proteins account for $20 \%$ of milk proteins and consist mainly of petalactoclobulin $(54 \%)$ and alpha-lactalbumin (21\%), as well as less serum albumin, aminoclobulin and peptone protease (Regalado et al., 2006). Whey is highly nutritious because it contains essential amino acids, vitamins, mineral salts and a good source of security acids such as leucine, isoleucine and valine. These acids help to synthesize protein, as well as tryptophan amino acid (Walzem et al., 2002). Whey acts as an antioxidant to inhibit free radicals and also works as antimicrobials because of its protective proteins such as lactoferrin, derivative peptides and lactoperoxidase. It has the ability to lower the level of cholesterol in the blood, prevent high blood pressure and word as anti-cancerous tumours. Thus, it controls the level of cellular glutathione. This reduces the risk of many diseases, including cancer, atherosclerosis, HIV, viral hepatitis, cardiovascular disease and osteoporosis. (Marshall, 2004). Many scientific studies have tended to take advantage of the whey in many various industrial and agricultural sectors (Al-Fayadh, 2009). The mechanism of magnetic technology was to obtain a set of changes in the chemical and physical properties of the treated liquid, including reducing the surface tension, viscosity, increase the polarity and reduce the number of water-forming molecules by dismantling the hydrogen bonds of these molecules together (Colic et al, 1998). The passage of water in the magnetic field causes the water molecules to bind in one direction. This arrangement leads to the breakdown of the hydrogen bond by the magnetic field energy, which changes the correlation angle from normal (less than 105) and the use of permanent magnets has reduced the surface tension of the treated liquids. Young \& Lee (2005) and Barefoot \& Reich (2002) explained that small groups of water molecules formed as a result of exposure to a magnetic field, which lead to better absorption and faster plant entry. The experiments conducted in some farms that used magnetic technology proved successfully in increasing the yield when growing citrus, field crops and some vegetables in the desert areas. It is a wellknown scientific basis that any living biological system when it exposed to certain magnetic fields will severely affect some of its biophysical properties in these fields, and may lead to cause change as an example of 
this change what happens to the seeds of exposure to external magnetic fields, it will affect the proportion of germination as well as effect on the growth rate of the plant (Davis, 1977). The study conducted by (Saruwatari, 1980) who proved that the magnetic treatment of many varieties of seeds before planting improved yields and that the treated seeds were early to germinate and mature. Ali et al. (2015) designed and manufactured a device to use in the cheese industry using a constant magnetic field with a density of 0.3 Tesla. The results showed an effect of the magnetic field on the chemical properties of milk, especially the moisture content, which increased significantly with increasing exposure time of the magnetic field. The results also exhibited a significant increase in titration acidity and a significant decrease in the total bacterial count and the amount of cheese produced from milk magnetization. In addition, the sensory evaluation showed that cheese made from magnetic milk was much better than hot pasteurized cheese.

The aim of this study was to investigate the effect of both acidic and magnetic enzyme and nonmagnetic whey on the physiological and productive traits of date palm cultivars and their utilization in these agricultural processes.

\section{Materials \& Methods}

This study was conducted during the growing season 2017-2018 in one of the private orchards in the district of Abu Al-Khaseeb Basrah. Two date palm cultivars were selected (yellow and green Shwithi). Five trees were selected from each cultivar. The trees were homogeneous in height and age (15-18) years and the trees were pollinated on 28/3/2018 with green pollination called Ghannami. The trees were sprayed with acidic, enzymatic and non-magnetic whey by three sprinkles between one and twenty days starting from the Hababouk stage at $100 \%$ concentration with the addition of the diffuser Tween 20.

\section{Physical characteristics of fruits}

\section{Fruit Weight (g)}

The soft weight of the fruit was calculated through weighing 10 fruits from each repeater using a sensitive electric balance Sartorius and then extracting the average soft weight of the fruit. The meat was separated from the seed and weighed with a sensitive balance. The dry weight of fruit samples was calculated after drying the fruit and seed pulpy in an electric oven at a temperature of $70{ }^{\circ} \mathrm{C}$ after 72 hours until the stability of the weight.

\section{Fruit Size (cm3)}

The size of the fruit was measured by the displacement of water using a cylinder and put the water to a certain extent and then put the full fruits (10 fruit) for each replicate in the cylinder. The average size of the fruit was determined according to the following equation:

$$
\text { fruit size }(\mathrm{cm} 3)=\frac{\text { Volume of water displaced }}{\text { Number of fruits in the sample }}
$$

\section{Average length and diameter of fruit $(\mathrm{cm})$}

The length and diameter of the fruit were measured using Vernier. The measurements were randomly tested for 10 fruit from each replicate. 


\section{Chemical properties of fruits}

The water content and dry matter content of the mixture was calculated using an electric :Water content $(\%)=$

$\frac{\text { Soft sample weight }- \text { Dry sample weight }}{\text { The sample weight is soft }} \times 100$

The dry matter is calculated by the following equation $=\frac{\text { Dry matter }(\%)}{\text { The sample weight is soft }} \times 100$

\section{Total Dissolved Solids (\%)}

Weigh $10 \mathrm{~g}$ of fresh fruit pulp was weighed, then $30 \mathrm{ml}$ of distilled water was added and mashed with using blender. The sample was filtered and the percentage of total soluble solids was measured using refract meter and the results were adjusted based on temperature $20{ }^{\circ} \mathrm{C}$ (Howrtiz, 1975).

\section{Total, Reduced Sugar and Sucrose (\%)}

The reduced sugar of fruit meat was estimated according to the Lane and Eynon's method based on dry weight (Howrtiz, 1975), which relies on the reduction of blue copper ions to red copper ions according to the following equation:

Reduced sugar $(\%)=$

$\mathrm{Mg}$ of sugar (from the table equivalent to reading burette)

$$
\text { Sample weight }
$$

x1000*Dilutions*100

Total converted sugar was estimated after 5 $\mathrm{ml}$ of concentrated hydrochloric acid was added to the porous sample. Then, $3 \mathrm{ml}$ lead acetate and $3 \mathrm{ml}$ potassium oxalate were added and left for 24 hours, after acidity neutralization with sodium hydroxide $(40 \%)$ and addition of drops of acetic acid in order to confirm the break-even point, the total sugars converted by Lane and Eynon were estimated according to the following formula:

Total sugars converted $(\%)=$ mg of sugar (from the table equivalent to reading burette) Sample weight

x 1000*Dilutions*100 oven at $70^{\circ} \mathrm{C}$. The water content and dry matter content were determined according to the below

equations
The percentage of sucrose (non-reducing sugars) is calculated by the following equation.

$$
\begin{aligned}
& \text { Sucrose }(\%)= \\
& \text { Total sugars converted }(\%)- \\
& \text { Reduced sugars }(\%) \times 0.95
\end{aligned}
$$

The following formula was applied to calculate the percentage of total sugars: Total

$$
\begin{aligned}
\text { sugars }(\%)= & \text { reductive sugars }(\%) \\
& + \text { sucrose }(\%) .
\end{aligned}
$$

\section{Enzymatic activity}

\section{Extraction solutions}

Solution (1) $0.06 \mathrm{M}$ ascorbic acid, prepared by dissolving $10.5678 \mathrm{~g}$ of ascorbic acid in volume of distilled water and completed to liters after adjusting $\mathrm{pH}$ ) to 7.5. Solution (2) phosphate regulator $0.25 \mathrm{M}$ potassium phosphate +0.06 molar ascorbic acid (= $7.5 \mathrm{pH}$ ), prepared the solution by dissolving $34.0225 \mathrm{~g}$ of potassium dihydrogen phosphate (KH2PO4) with $10.5678 \mathrm{~g}$ of ascorbic acid in volume of distilled water and completed volume to 1 litre after Adjust the $\mathrm{pH}$ to 7.5.

\section{Enzymatic activity test solutions}

The first Solution was phosphate $2 \mathrm{M}$ at $(\mathrm{pH}$ $=4.7$ ), which prepared

According to the method described by Christian (1980) by dissolving $11.66 \mathrm{~g}$ of potassium phosphate $\left(\mathrm{KH}_{2} \mathrm{PO}_{4}\right)$ with $2.58 \mathrm{~g}$ of sodium phosphate $\left(\mathrm{Na}_{2} \mathrm{HPO}_{4} \cdot 2 \mathrm{H}_{2} \mathrm{O}\right)$ in a given volume of distilled water. Then, the 
volume was completed to $1 \mathrm{~L}$ with distilled water after $\mathrm{pH}$ was adjusted to 4.7 using 0.01 $\mathrm{HCl}$ solution. The sucrose solution $0.1 \mathrm{M}$ was prepared by dissolving $34.2 \mathrm{~g}$ of sucrose per liter of phosphate buffer solution 1. This solution was used to measure the efficacy of the invertase enzyme after adjusting the $\mathrm{pH}$ value to 4.0. The solution (3) DNSA (3, 5 Di Nitro Salicylic Acid) was prepared according to the method described by Howrtiz (1975) as follows:

1-Preparing $150 \mathrm{ml} \mathrm{NaOH}$ at a concentration of $4.5 \%$ by dissolving $6.75 \mathrm{~g} \mathrm{NaOH}$ in $250 \mathrm{ml}$ distilled water.

2-Preparing $400 \mathrm{ml}$ of DNSA at a concentration of $1 \%$ by dissolving $4 \mathrm{~g}$ of DNSA in $400 \mathrm{ml}$ distilled water. After good dissolution, a solution of sodium hydroxide was added.

3-The mixture was added in above $1.275 \mathrm{~g}$ Rochelle salt. The DNSA solution was used as a reagent in the determination of reducing sugars resulting from cellulose decomposition by cellulase.

Solution (4) CMC solution (Carboxy methyl Cellulose 1\%), Prepare the solution by dissolving $1 \mathrm{~g}$ of carboxy methyl cellulose in $100 \mathrm{ml}$ of phosphate buffer solution (Solution 1), CMC solution was added to the regulated solution by $1 \%$ gradually with constant stirring to dissolve it This solution was used to measure cellulase enzyme activity after adjusting $\mathrm{pH}$ to 5.0 .

\section{Extraction method}

$10 \mathrm{~g}$ of dehydrated frozen fruit De-cores was Randomly weighed, cut into small pieces and crushed in a $4{ }^{\circ} \mathrm{C}$ cooled mortar placed in an ice cube after adding $25 \mathrm{ml}$ of extraction solution (1). Then, the mixture was filtered through a filter paper and wash the precipitate Remaining again using $25 \mathrm{~mL}$ of the same extraction solution and filtered through filter paper, mix the washed precipitate with extraction solution (2) at the same extraction rate, and filter the mixture as in the method above, and use the filtrate (enzyme solution) to estimate the effectiveness of the enzyme invertase only. The Andrology method (AlBakir \& Whitaker, 1978).

\section{Estimation of invertase enzyme activity}

The efficacy of the enzyme was tested by taking $5 \mathrm{ml}$ of test solution 2 (sucrose), the enzyme subject in a test tube and incubated for 5 minutes at $35^{\circ} \mathrm{C}$, then added to each tube $0.5 \mathrm{ml}$ of the enzyme solution (this marks the beginning of the reaction). It was then placed in a water bath at $35^{\circ} \mathrm{C}$ and left for 20 minutes, then added to each tube 0.5 $\mathrm{ml}$ of test solution No. 3, the tubes were cooled with cold water and then according to the spectrum absorption of each sample in the Spectrophotometer at a wavelength of 540 $\mathrm{nm}$, in the same way. Prepare a solution of zero or a blank solution with the addition of $0.5 \mathrm{ml}$ of the solution Tabar No. 1 (phosphate buffer solution) solution instead of the enzyme.

\section{Determination of cellulase enzyme activity}

In the same way above the cellulase enzyme activity was estimated except for the use of solution 4 (carboxy methyl cellulose) as a reactant instead of sucrose.

\section{Product components}

\section{Percentage of precipitation}

Five shamariks were randomly selected from each raceme, count the number of ripe fruits, the number of non-ripe fruits (sheis) and the number of empty scars after 40 days of pollination.

The percentage of the fruit contract was estimated using the following equation: 
Percentage of fruit fall $=1+$

$\frac{\text { Number of empty scars }}{\text { Total number of fruits }} \times 100$

Fruit ripening rate
The fruit ripening rate was calculated by taking five Shamrakhs randomly from each raceme after each wet and using the following equation:

$$
\text { Fruit ripening percentage }=\frac{\text { Number of ripe fruits }}{\text { Total number of fruits }} \times 100
$$

\section{Productivity per kg $(\mathbf{k g})$}

The productivity was calculated for one raceme in the wet stage by placing the raceme in a special bag prepared for this purpose, then cutting the raceme according to the number of fruits and weighing with a field balance.

\section{Bunch weight (kg)}

Palm productivity was estimated by multiplying the average yield per single feed in the previous paragraph and for each treatment by the number of racemes per palm (6 raceme.palm $\left.{ }^{-1}\right)$.

\section{Sweet whey}

Sweet whey was obtained from the residues of soft cheese industry, which was from pasteurized cow's milk, the remnants of the curd were eliminated by filtration and the remaining whey was preserved in elastic bags and kept at $-18^{\circ} \mathrm{C}$ until used.

\section{Extraction of whey proteins}

Conventional method: whey proteins are extracted in thermal denaturize, where the whey was heated to $85 \%{ }^{\circ} \mathrm{C}$ for 15 minutes. This was followed by the filtration procedure and the washing of the curd with water to get rid of salts and lactose sugar until the washing water became clear, then dried proteins deposited in an oven ventilated at a temperature of $45 \%$ and then milled dried thrombus by the home coffee grinder Moulinex type (Devilbiss., 1974). In contrast unconventional method was done as follows: salts and lactose were eliminated using dialysis membranes with a certain volume of whey proteins and closed well and then suspended in a glass container filled with distilled water at $7{ }^{\circ} \mathrm{C}$. For one full night, the concentration of the protein solution in the rotary evaporator was followed to the desired concentration (20, 25 and $30 \%$ solid) (Devilbiss, 1974).

\section{Milk Magnetization Device (Figs. 1-2)}

The device was designed and manufactured by Ali et al. (2015) in Food Engineering Laboratory, Department of Food Science, University of Basrah. The device consists of a structure (5) made of wood and two fixed magnets (8) the intensity of each (Tesla $0.365)$ and the distance between them $(0.5 \mathrm{~cm})$ and put the North Pole versus the South Pole and put between them a transparent plastic tube (2) diameter $(1 \mathrm{~cm})$ and it contains a reciprocating pump (12) v12 discharged (10L/min) tied to wires (11) pulls milk from the bottom of the tank (3) capacity L5 and pushes it towards the fixed magnet (8) as it is exposed to magnetic energy and returns to the tank (3) The system is equipped with a battery with a capacity of Ah90 and is equipped with a voltage of v12 (13) and there is a tube (4) with a valve (14) used to exit the magnetic whey.

\section{Mechanism of operation of the device}

When the tank is filled with whey (3) the valve is closed (14), the switch (7) is switched and the electric current is passed to the pump (12). The latter pulls the whey from the bottom of the tank (3) and pushes it into 
the plastic tube (10) and passes between the two poles of the magnet (8) then push through the tube (2) to the tank (3) so that the whey has been magnetized and when it is intended to increase the period of exposure to the magnet we make it through the magnet for periods.
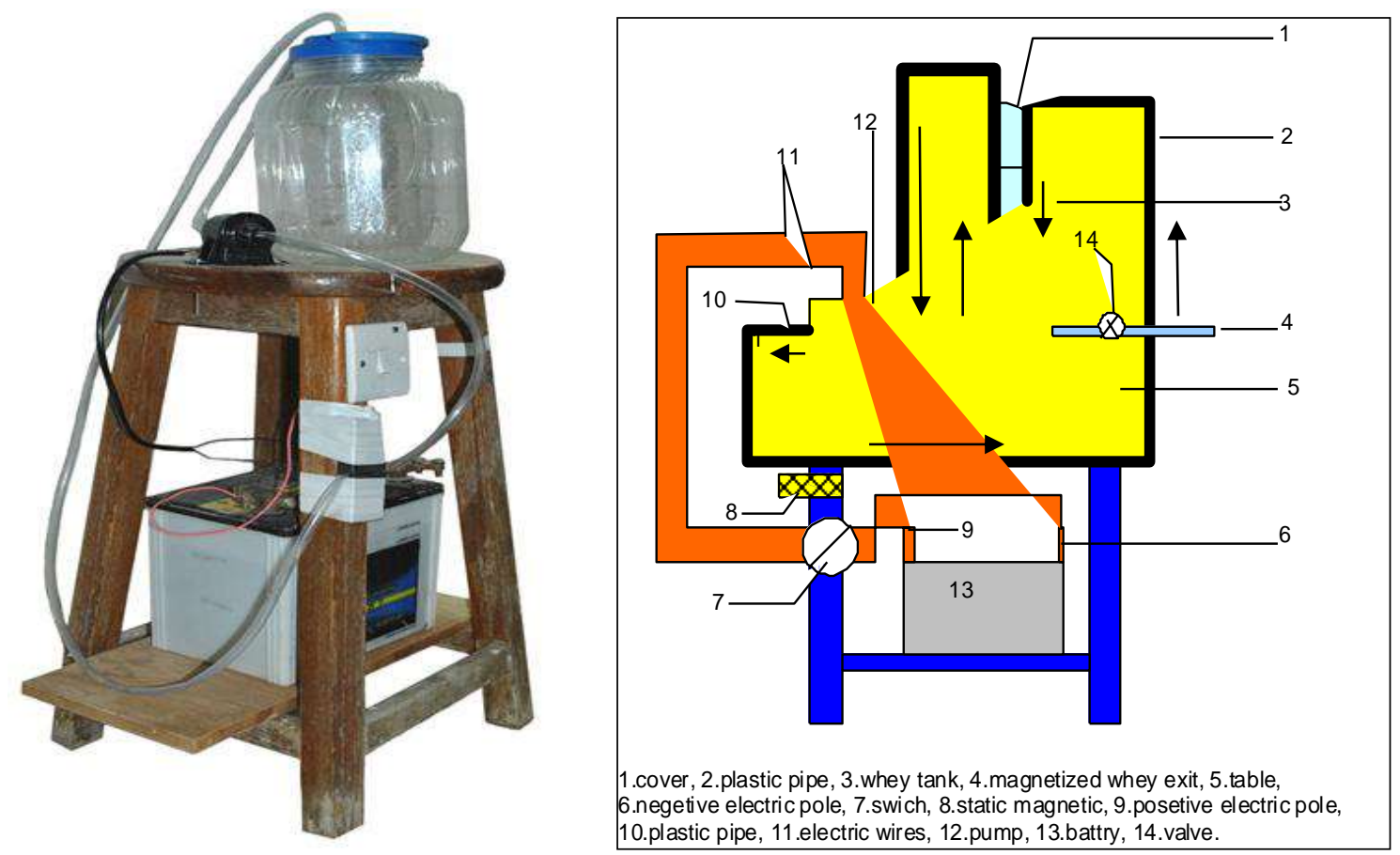

Fig. (1): Locally produced milk magnetizer, Fig. (2): Image of locally produced milk magnetizer.

\section{Statistical analysis}

The experiments were carried out according to CRD analysis of five palm trees per treatment (replicates). Two factors, namely (two classes) and spray treatment (five spraying factors). SPSS was used to analyse the data, and the least significant RLSD test was used to compare averages (Bashir, 2003).

\section{Results}

Table (1) shows that the Khdrawi variety superior regarding the characteristic of the length of the fruit, as it scored $26.10 \mathrm{~mm}$.
Also, the results showed the significant superiority of the treatment of spraying with magnetic enzyme spray compared to the other study treatments, while the comparison treatment recorded the lowest values of the same characteristic, which reached $19.45 \mathrm{~mm}$. It is noted from the bilateral interference that the treatment of the vegetable cultivar and the spraying with the magnetized enzyme spray were significantly superior to the rest of the treatments, while the treatment of the Shwithi cultivar and spraying with distilled water (comparison) was the lowest values, which were $19.24 \mathrm{~mm}$. 
Ali et al., / Basrah J. Agric. Sci., 34(2): 10-28, 2021

Table (1): Effect of cultivar and coefficients of spraying with acid and enzyme whey magnetized and non-magnetized on fruit length $(\mathrm{mm})$.

\begin{tabular}{lcccc}
\hline Treatments & Khdrawi & Shwithi & Mean & RLSD \\
\hline Acidic & $19.77 \pm$ & $19.83 \pm$ & $19.80 \pm$ & \\
\hline Enzymatic & $20.29 \pm$ & $20.91 \pm$ & $20.60 \pm$ & \\
\hline Magnetized Acidic & $21.53 \pm$ & $21.83 \pm$ & $21.68 \pm$ & \\
\hline Magnetized enzymatic & $26.10 \pm$ & $22.46 \pm$ & $24.28 \pm$ & \\
\hline Control & $19.24 \pm$ & $19.45 \pm$ & $19.35 \pm$ & \\
\hline Mean & $21.39 \pm$ & $20.89 \pm$ & & 1.400 \\
\hline RLSD & \multicolumn{3}{c}{2.214} & \\
\hline RLSD interaction & 3.131 & & \\
\hline
\end{tabular}

Table (2) shows that the Shuwaithi variety did not significantly outweigh the fruit diameter compared with Al-Khdrawi variety, which scored 37.38 and $35.74 \mathrm{~mm}$, respectively. The treatment of spraying with magnetized enzyme spray recorded the highest fruit diameter, significantly $34.55 \mathrm{~mm}$, and the comparative treatment had the lowest value in this characteristic of $30.07 \mathrm{~mm}$.The obtained results also showed that the Shwithi cultivar and the magnetized enzyme spraying exhibited the highest value of the fruit diameter which was $35.96 \mathrm{~mm}$, with a clear significant difference from the rest of the study treatments.

Table (2): Effect of class and sprinkler treatments with acid and non-magnetic enzymes on fruit diameter $(\mathbf{m m})$.

\begin{tabular}{lcccc}
\hline Treatments & Khdrawi & Shwithi & Mean & RLSD \\
\hline Acidic & 30.53 & 37.38 & 31.01 & \\
\hline enzymatic & 32.70 & 35.74 & 32.33 & \\
\hline Magnetized Acidic & 34.41 & 31.97 & 35.08 & \\
\hline Magnetized enzymatic & 34.55 & 31.49 & 35.96 & \\
\hline Control & 30.07 & 30.68 & 30.38 & \\
\hline Mean & 32.45 & 32.45 & & 0.524 \\
\hline RLSD & & & 0.828 & \\
\hline RLS. D interaction & 1.171 & & \\
\hline
\end{tabular}

Table (3): Effect of variety and spray treatments with acid and enzyme magnetized and nonmagnetism on fruit size $\left(\mathrm{cm}^{3}\right)$.

\begin{tabular}{lcccc}
\hline Treatments & Shwithi & Khdrawi & Mean & RLSD \\
\hline Acidic & 9.350 & 11.200 & 9.383 & \\
\hline enzymatic & 9.633 & 9.867 & 9.683 & \\
\hline Magnetized Acidic & 9.767 & 9.733 & 9.817 & \\
\hline Magnetized enzymatic & 10.250 & 9.417 & 10.725 & \\
\hline Control & 8.633 & 8.317 & 8.475 & \\
\hline Mean & 9.527 & 9.707 & & 0.1549 \\
\hline RLSD & \multicolumn{3}{c}{0} & \\
\hline RLS.D interaction & 0.3463 & & \\
\hline
\end{tabular}


Table (3) shows that Al-Khdrawi group was significantly superior in size characteristic compared to the Shwithi cultivar, where it recorded $9.767 \mathrm{~cm}^{3}$ and the treatment of spraying with magnetic enzyme whey compared to the rest of the study treatments was $10.725 \mathrm{~cm}^{3}$. The bending interference had a clear moral effect, as the treatment of the vegetable variety and the treatment of sprinkling with magnetic whey were superior in comparison with other study treatments. Table (4) shows that the vegetable Khdrawi had a significant enhanced in term of the fruit weight attribute. It recorded $9.302 \mathrm{~g}$, while the Shwithi cultivar recorded $9.218 \mathrm{~g}$ with a significant difference. Also, the statistical analysis of this table showed the superiority of the treatment of sprinkling enzyme magnetized in the characteristic of fruit weight and significantly compared to the rest of the treatments as it reached $9.917 \mathrm{~g}$. The binary interference also had a statistical effect, where the treatment of the vegetable variety and the treatment of spraying with magnetic enzyme whey were superior compared to most of the study treatments, and they recorded $9.883 \mathrm{~g}$. Table (5) shows that there were no significant differences between the two types, Al-Shwithi and Al-Khdrawi regarding the characteristic of the water content, and that the comparison treatment exceeded the same characteristic of the spray treatment as it recorded 63.368. The two- way overlap had a significant moral effect on the superiority of the comparison treatment with the Shwithi cultivar in the water content characteristic, reaching 63,320 g.

Table (4): Effect of cultivar and sprinkler treatments with acid and enzyme magnetized and non-magnetized on fruit weight (g).

\begin{tabular}{|c|c|c|c|c|}
\hline Treatments & Shwithi & Khdrawi & Mean & RLSD \\
\hline Acidic & 8.700 & 9.950 & 8.752 & \\
\hline enzymatic & 9.300 & 9.717 & 9.350 & \\
\hline Magnetized Acidic & 9.607 & 9.400 & 9.622 & \\
\hline Magnetized enzymatic & 9.883 & 8.803 & 9.917 & \\
\hline Control & 8.900 & 8.640 & 8.620 & \\
\hline Mean & 9.218 & 9.302 & & 9.0992 \\
\hline RLSD & & & 0.1569 & \\
\hline RLSD interaction & \multicolumn{2}{|c|}{2218.0} & & \\
\hline
\end{tabular}

Table (5): Effect of cultivar and acid and non-magnetostatic sprinkler treatments on weight of water content (\%).

\begin{tabular}{lcccc}
\hline Treatments & Shwithi & Khedrawi & Mean & RLSD \\
\hline Acidic & 62.863 & 62.987 & 62.925 & \\
\hline enzymatic & 62.687 & 62.150 & 62.418 & \\
\hline Magnetized Acidic & 61.907 & 61.703 & 61.805 & \\
\hline Magnetized enzymatic & 60.797 & 61.320 & 61.058 & \\
\hline Control & 63.320 & 63.417 & 63.368 & \\
\hline Mean & 62.315 & 62.315 & & 0.3076 \\
\hline RLSD & \multicolumn{3}{c}{0.4864} & \\
\hline RLSD interaction & 0.6879 & & \\
\hline
\end{tabular}


Ali et al., / Basrah J. Agric. Sci., 34(2): 10-28, 2021

Table (6) Effect of cultivar and spray treatments with acid and enzyme magnetized and nonmagnetized on dry weight (\%)

\begin{tabular}{|c|c|c|c|c|}
\hline Treatments & Shwithi & Khdrawi & Mean & RLSD \\
\hline Acidic & 37.137 & 37.013 & 37.075 & \\
\hline enzymatic & 37.313 & 37.850 & 37.582 & \\
\hline Magnetized Acidic & 38.093 & 38.297 & 38.195 & \\
\hline Magnetized enzymatic & 39.203 & 38.680 & 38.942 & \\
\hline Control & 36.680 & 36.583 & 36.632 & \\
\hline Mean & 37.685 & 37.685 & & 0.3076 \\
\hline RLSD & & & 0.4864 & \\
\hline RLSD interaction & & & & \\
\hline
\end{tabular}

The results of this table (6) act the same trend as the results of the table of water content. The results show no significant differences between the classes regarding the dry substance characteristic. The treatment of spraying with enzymatic and acidic whey was superior compared to other treatments in the same characteristic, as it recorded 38,680 and 38,297 g, respectively. The two-way interaction had a statistically significant effect, as it was significantly distinguished by the treatment of enzymatic sprinkling of the Shwithi variety by giving the highest values, which did not differ significantly compared with the vegetative variety and sprinkling with enzymatic whey. It was recorded 39.203 and $38.680 \mathrm{~g}$, respectively.

Table (7): Effect of cultivar and acid and non-magnetostatic sprinkler treatments on percentage of total sugars. $(\%)$.

\begin{tabular}{|c|c|c|c|c|}
\hline Treatments & Shwithi & Khdrawi & Mean & RLSD \\
\hline Acidic & 48.16 & 48.06 & 48.11 & \\
\hline enzymatic & 48.54 & 48.87 & 48.70 & \\
\hline Magnetized Acidic & 50.77 & 51.04 & 50.91 & \\
\hline Magnetized enzymatic & 56.15 & 56.24 & 56.19 & \\
\hline Control & 47.17 & 47.18 & 47.17 & \\
\hline Mean & 50.16 & 50.28 & & 0.792 \\
\hline RLSD & & & 1.252 & \\
\hline RLSD interaction & & & & \\
\hline
\end{tabular}

There were no significant differences between the cultivars in the total sugars characteristic as shown in the table (7). It reached 50.16 and $50.28 \%$ for the two classes of Shwithi and Al-Khdrawi, respectively. While the sprinkling with enzymatic whey was significantly increased in the characteristics of total sugars compared to other study coefficients, which reached $56.24 \%$. Table (8) shows the superiority of the date palm Al-
Khdrawi compared to Al-Shwithi cultivar in the percentage of reducing sugars, while the Al-Shwithi cultivar recorded $35.47 \%$. The treatment of enzyme sprinkling was $38.09 \%$ compared to other study treatments. The comparison treatment recorded the lowest values and a significant difference with the rest of the studied treatments $34.07 \%$. The vegetable variety by using enzyme sprinkling was significantly increased in the same trait 
and recorded $38.43 \%$. Table (9) shows that the Shwithi cultivar did not significantly differ in the percentage of sucrose compared to the vegetative Khdrawi, and the values were 13.10 and $13.17 \%$, respectively. The treatment of acid sprinkling was significantly higher in the same trait, which did not differ significantly with the comparison treatment. The enzymatic sprinkler treatment recorded the lowest values $10.03 \%$. In contrast, the binary overlap showed that the lowest values were recorded, with a significant difference with most of the study treatments, which was $9.91 \%$. There were no significant difference between the cultivars included in the study Al-Shwithi and Al-Khdrawi (Table 10). The bilateral interaction had a significant effect through the data of table (10) by registering the treatment of the green variety and spraying with enzymatic spill over the highest data, $56.47 \%$, and the comparison treatment for the Shwithi cultivar recorded the lowest values of $51.27 \%$.

Table (8): Effect of cultivar and spray treatments with acid and enzyme magnetic and nonmagnetic in the percentage of reducing sugars. $\%$ )

\begin{tabular}{|c|c|c|c|c|}
\hline Treatments & Shwithi & Khdrawi & Mean & RLSD \\
\hline Acidic & 34.42 & 35.28 & 34.85 & \\
\hline enzymatic & 34.99 & 35.69 & 35.34 & \\
\hline Magnetized Acidic & 36.13 & 36.96 & 36.54 & \\
\hline Magnetized enzymatic & 37.74 & 38.43 & 38.09 & \\
\hline Control & 34.06 & 34.08 & 34.07 & \\
\hline Mean & 35.47 & 36.09 & & 0.511 \\
\hline RLSD & & & 0.807 & \\
\hline RLSD interaction & & & & \\
\hline
\end{tabular}

Table (9): Effect of cultivar class with acid and enzyme magnetizing and non-magnetizing spray coefficients on percentage of sucrose $(\%)$.

\begin{tabular}{lcccc}
\hline Treatments & Shwithi & Khdrawi & Mean & RLSD \\
\hline Acidic & 13.74 & 12.79 & 13.26 & \\
\hline enzymatic & 11.40 & 13.17 & 12.29 & \\
\hline Magnetized Acidic & 11.11 & 10.41 & 10.76 & \\
\hline Magnetized enzymatic & 10.15 & 9.91 & 10.03 & 0.892 \\
\hline Control & 13.11 & 13.10 & 13.11 & \\
\hline Mean & 11.90 & 11.88 & & \\
\hline RLSD & \multicolumn{5}{c}{1.995} & & \\
\hline RLSD interaction & & & & \\
\hline
\end{tabular}


Ali et al., / Basrah J. Agric. Sci., 34(2): 10-28, 2021

Table (10): Effect of class and spray treatments with acid and enzyme magnetism and non-magnetism in the percentage of soluble solids (\%).

\begin{tabular}{|c|c|c|c|c|}
\hline Treatments & Shwithi & Khdrawi & Mean & RLSD \\
\hline Acidic & 52.64 & 52.65 & 52.65 & \\
\hline Enzymatic & 53.61 & 54.02 & 53.82 & \\
\hline Magnetized Acidic & 55.36 & 55.60 & 55.48 & \\
\hline Magnetized enzymatic & 56.38 & 56.47 & 56.43 & \\
\hline Control & 51.27 & 51.31 & 51.29 & \\
\hline Mean & 53.85 & 54.01 & & 0.614 \\
\hline RLSD & & & 0.971 & \\
\hline RLSD interaction & \multicolumn{2}{|c|}{1.373} & & \\
\hline
\end{tabular}

Table (11) reveals that there were no significant differences between the classes in the characteristic of invertase enzyme, which amounted to 2327.8 and 2347.1 units $/ \mathrm{kg} / \mathrm{CO}_{2}$, and the treatment of enzyme sprinkling was significantly superior compared to other study coefficients 2614.8 units $/ \mathrm{kg} / \mathrm{CO}_{2}$, and recording the highest data for the class treatment Al-Khdrawi and sprinkling with enzyme whey for the same characteristic

Table (11): Effect of cultivar and spray treatments with acid and enzyme magnetized and non-magnetized inverts.

\begin{tabular}{lcccc}
\hline Treatments & Shwithi & Khdrawi & Mean & RLSD \\
\hline Acidic & 2237.7 & 2260.3 & 2249.0 & \\
\hline Enzymatic & 2281.7 & 2312.7 & 2297.2 & \\
\hline Magnetized Acidic & 2383.0 & 2402.7 & 2392.8 & \\
\hline Magnetized enzymatic & 2605.3 & 2624.3 & 2614.8 & 34.33 \\
\hline Control & 2131.3 & 2135.7 & 2133.5 & \\
\hline Mean & 2327.8 & 2347.1 & & \\
\hline RLSD & & & & \\
\hline RLSD interaction & & & & \\
\hline
\end{tabular}


amounted to 2624.3 units $/ \mathrm{kg} / \mathrm{CO}_{2}$, and the lowest data were recorded for the comparison treatment of the Shuithi cultivar 2131.3 units/ $\mathrm{kg} / \mathrm{CO}_{2}$.

Table (12) were designed in the same direction as the results of the previous table in the absence of significant differences between the varieties and the superiority of treatment with spraying enzyme as well as treatment of Shwithi class and spraying with enzyme whey 2307.3 units $/ \mathrm{kg} / \mathrm{CO}_{2}$. Table (13) exhibited that the date palm tree variety was significantly superior in the percentage of precipitation $16.12 \%$. The treatment of enzymatic sprinkling recorded the lowest values in the drop percentage $12.91 \%$ and the bilateral interaction had a clear effect according to the statistical analysis. The shwithi variety was recorded the highest values in the rate of precipitation. The lowest values were recorded for the vegetative variety and the treatment of enzyme sprinkling was $12.82 \%$.

Table (14) shows that the date palm cultivar was enhanced in terms of percentage of ripeness, with a score of $76.29 \%$. The treatment of sprinkling with enzyme whey significantly increased, as it was $79.78 \%$. The table also shows that the treatment of the vegetable variety and sprinkling with enzymatic sprinkling was $81.73 \%$, while the Shwithi cultivar recorded the lowest values.

Table (12): Effect of cultivar and spray treatments with acid and enzyme magnetized and non-magnetic for cellulose

\begin{tabular}{lcccc}
\hline Treatments & Shwithi & Khdrawi & Mean & RLSD \\
\hline Acidic & 1884.0 & 1887.7 & 1885.8 & \\
\hline enzymatic & 2080.3 & 2122.0 & 2101.2 & \\
\hline Magnetized Acidic & 2215.3 & 2234.7 & 2225.0 & \\
\hline Magnetized enzymatic & 2307.3 & 2264.7 & 2286.0 & \\
\hline Control & 1854.0 & 1866.3 & 1860.2 & \multirow{2}{*}{36.92} \\
\hline Mean & 2068.2 & 2075.1 & & \\
\hline RLSD & \multicolumn{5}{c}{58.38} & \\
\hline RLSD interaction & 82.56 & & \\
\hline
\end{tabular}


Ali et al., / Basrah J. Agric. Sci., 34(2): 10-28, 2021

Table (13): Effect of cultivar and acid and non-magnetostatic sprinkler treatments on percentage of precipitation (\%).

\begin{tabular}{|c|c|c|c|c|}
\hline Treatments & Shwithi & Khdrawi & Mean & RLSD \\
\hline Acidic & 16.79 & 15.41 & 16.10 & \\
\hline Enzymatic & 15.91 & 15.19 & 15.55 & \\
\hline Magnetized Acidic & 15.15 & 13.85 & 14.50 & \\
\hline Magnetized enzymatic & 13.00 & 12.82 & 12.91 & \\
\hline Control & 19.74 & 17.74 & 19.74 & \\
\hline Mean & 16.12 & 15.40 & & 0.603 \\
\hline RLSD & & & 0.959 & \\
\hline RLSD interaction & \multicolumn{2}{|c|}{1.356} & & \\
\hline
\end{tabular}

Table (14): Effect of cultivar and spray treatments with acid and enzyme magnetism and nonmagnetism on percentage of maturity (\%).

\begin{tabular}{lcccc}
\hline Treatments & Shwithi & Khdrawi & Mean & RLSD \\
\hline Acidic & 72.81 & 73.96 & 73.38 & \\
\hline Enzymatic & 75.15 & 76.02 & 75.59 & \\
\hline Magnetized Acidic & 77.19 & 78.48 & 77.84 & \\
\hline Magnetized enzymatic & 77.83 & 81.73 & 79.78 & 1.001 \\
\hline Control & 70.84 & 71.25 & 71.04 & \\
\hline Mean & 74.77 & 76.29 & & \\
\hline RLSD & \multicolumn{5}{c}{2.583} & \\
\hline RLSD interaction & \multicolumn{2}{c}{2.239} & & \\
\hline
\end{tabular}

Table (15) shows that the Al-Khdrawi cultivar was significantly better based on the fresh weight. It recorded $15.674 \mathrm{~kg}$ compared to the Shwithi cultivar, which recorded $13.868 \mathrm{~kg}$. The treatment of the vegetative variety and the enzyme arch by recording the highest values was $16,310 \mathrm{~kg}$. Table (16) also expressed the same context of the previous table (15) regarding the superiority of the vegetable variety. 
Ali et al., / Basrah J. Agric. Sci., 34(2): 10-28, 2021

Table (15): Effect of cultivar and spray treatments with acid and enzyme magnetism and nonmagnetism on fresh weight $(\mathrm{kg})$.

\begin{tabular}{lcccc}
\hline Treatments & Shwithi & Khdrawi & Mean & RLSD \\
\hline Acidic & 13.447 & 15.303 & 14.375 & \\
\hline enzymatic & 13.963 & 15.703 & 14.833 & \\
\hline Magnetized Acidic & 14.387 & 16.083 & 15.235 & \\
\hline Magnetized enzymatic & 14.557 & 16.310 & 15.433 & \\
\hline Control & 12.987 & 14.970 & 13.978 & \\
\hline Mean & 13.868 & 15.674 & & 0.2697 \\
\hline RLSD & \multicolumn{3}{c}{0.4264} & \\
\hline RLSD interaction & 0.6030 & & \\
\hline
\end{tabular}

Table (16): Effect of cultivar and spray treatments with acid and enzyme magnetized and non-magnetized in the bunch weight $(\mathrm{kg})$.

\begin{tabular}{|c|c|c|c|c|}
\hline Treatments & Shwithi & Khdrawi & Mean & RLSD \\
\hline Acidic & 80.68 & 91.82 & 86.25 & \\
\hline Enzymatic & 83.78 & 94.22 & 89.00 & \\
\hline Magnetized Acidic & 86.32 & 96.50 & 91.41 & \\
\hline Magnetized enzymatic & 87.34 & 97.86 & 92.60 & \\
\hline Control & 77.92 & 89.82 & 83.87 & \\
\hline Mean & 83.21 & 94.04 & & 1.618 \\
\hline RLSD & & & 2.558 & \\
\hline RLSD interaction & \multicolumn{2}{|c|}{3.618} & & \\
\hline
\end{tabular}




\section{Discussion}

Magnetic treatment has led to an improvement in the physical and productive properties of date palms. The positive effects of magnetically treated whey may be related to the fact that the magnetically treated whey helps in increasing the movement of nutrients as well as increasing the solubility of some chemical compounds and converting them into ions absorbed by the plant, thus the growth of plant was increased (Estiken \& Turan, 2004; Dinali et al., 2020). The magnetic field also can lead to the dismantling of hydrogen bonds linking water molecules, which reduces the number of molecules accumulated and these small clusters make it lighter and easier to enter the cells. (Allen et al, 2006; Wang et al., 2020). Moreover, the magnetic treatment reduces surface tension, viscosity and fluid density, making it easier to absorb. The magnetically treated whey was better and superior compared to the untreated whey due to the fact that the changes in the physical and chemical properties of magnetized whey represented by the reduction of surface tension, density and viscosity. Hilal \& Hilal (2004) noted that the magnetic field weakens the hydrogen bonds of water molecules, reducing the number of water molecules accumulated and facilitating their absorption. In addition, the polarity of the treated whey molecules was increased and this dissolution of minerals and salts were increased. The magnetism improves the properties of whey kinetic and dissolved materials and thus absorption of nutrients by the plant was enhanced.

The role of both magnetic sweet and sour whey is to increase the growth of plants and effect positively to enhance the productive plant because the magnetic field could work to increase the amount of dissolved oxygen, especially in the medium in which the roots grow, and change some physical properties such as low surface tension, viscosity and density (Barefoot \& Reich, 2002; Miroslav \& Morse (1998). The absorption of components created from sweet and sour whey by magnetic treatment will be easily from the cells, thus increasing the plant activity and enhancing the process of absorption of the basic elements needed by the plant. These results in an increased division and elongation of leaf cells and an increase in their breadth (Khattab et al. 2000) due to its ability to reduce the resistance of cell walls to cell elongation during growth processes and to improve the absorption and transport of elements through the plant tissue, therefore, this led to an increase in the formation, division of leaf cells and the photosynthetic products (O'kiely \& O'Rordan, 1998; Munir et al., 2020; Khalaf et al., 2020).

\section{Ethics approval and consent to participate}

Not applicable for this section

\section{Conflict of Interest}

All authors declares no conflict of interests

\section{Acknowledgement}

The authors wish to thank the officials of the Dairy Chemistry Laboratory at the College of Agriculture, University of Basrah, to provide the required quantities of whey.

\section{Orcids}

H. I. Ali http://orcid.org/0000-0001-5185-6093

A. M. Abd https://orcid.org/0000-0002-26959485 


\section{Ali et al., / Basrah J. Agric. Sci., 34(2): 10-28, 2021}

W. H. Khassaf https://orcid.org/0000-00018329-8436

\section{References}

Al-Fayadh, H. M. S. (2009). The use of whey and natural foodstuffs in the water-ice-like industry. M. Sc. Thesis, College of Agriculture and Forestry, University of Mosul. 79pp.

Allen F, E., Luck, P. J., \& Davis, J. P. (2006). Factors determining the physical properties of protein foams, Food Hydrocolloids, 20, 284-292. https://doi.org/10.1016/j.foodhyd.2005.03.014

Al-Bakir, A., \& Whitaker, J. R. (1978). Purification and characterization of invertase from dates (Phoenix dactylifera L., var. Zahdi). Journal Food Biochemistry, 2, 133-160. https://doi.org/10.1111/j.1745-4514.1978.tb00609.x

Ali, H. I., Alhilphy, A. R. S., \& Aldarwish, A. K. (2015). The effect of magnetic field treatment on the characteristics and yield of Iraqi local white cheese. IOSR Journal of Agriculture and Veterinary Science, 8, 63-69. https://doi.org/10.9790/2380-08926369

Barefoot, R. R., \& Reich, C. S. (2002). The calcium factor: The scientific secret of health and youth. South eastern. PA: Triad Marketing; 5th edition, 218pp. https://www.amazon.com/Calcium-FactorScientific-Secret-Health/dp/0963370324

Barreveld, W. H. (1993). Date palm products. FAO Agricultural services Bulletin, No. 101, 231pp http://www.fao.org/docrep/t0681e/t0681e00.htm

Bashir, S Z. (2003). Your guide to the SPSS statistical program. The Arab Institute for Statistical Training and Research, 246 pp.

Christian, G. D. (1980). Analytical Chemistry $.3^{\text {rd }}$ edition John Wiley and Sons. New York, University of Washington, 186pp.

Colic, M., Chien, A., \& D. Morse, D. (1998). Synergistic application of chemical and electromagnetic water treatment in corrosion and scale prevention. Croatica Chemica Acta, 71, 905-916. https://www.semanticscholar.org/paper/SYNERGIS TIC-APPLICATION-OF-CHEMICAL-ANDWATER-AND-\%C4\%8Coli\%C4\%87-
Chien/df88a874b3df857691a481e86912a4c05ef2e75

e

Davis, A. R. (1977). Apparatus and Method for Exposing Seeds to a Magnetic Field. US. Patent, No. 4020590. 175pp. https:// patents.google.com/ patent/us4020590A/en

Dinali, L. A. F., Oliveira,' H. L., Teixeira, L. S., Silva, A. T. M., AD'Oliveira, K., Cuin, A., \& Borges, K. B. (2020). Efficient development of a magnetic molecularly imprinted polymer for selective determination of trimethoprim and sulfamethoxazole in milk. Microchemical Journal, 154, 104648 https://doi.org/10.1016/j.microc.2020.104648

Devilbiss, E. D., Holsinger, V. H., Posati, L. P., \& Pallansch, M. J. (1974). Properties of whey protein concentrate foams, Journal. Food Technology, 28, 40-48. https://agris.fao.org/agrissearch/search.do?recordID=US201303132543

Estiken, A., \& Turan, M. (2004). Alternating magnetic field effects on yield and plant nutrient elements composition of strawberry (Fragaria ananassa CJ Camarosa). Agriculture Scandinavica section B-Soil and Plant Science, 54, 135-139. https://doi.org/10.1080/09064710310019748

Hilal, M. H., \& Hilal, M. M. (2004). Application of magnetic technology in desert agriculture. I. seed germination and seedling emergence of some crops in a saline calcareous soil. Egypt Journal Soil Science, 40, 413-422. https://agris.fao.org/agrissearch/search.do?recordID=EG2003000368

Howrtiz, W. (1975). Official Methods of Analysis. Association of Official Analytical Chemists. Washington, D. C., 1049pp. https://doi.org/10.1002/jps.2600650148

Ibrahim, A. O. (2008). Date Palm Tree of Life. Arab Center for the Studies of Arid Zones and Arid Lands (ACSAD). Damascus, 390pp. https://doi.org/10.1007/978-94-017-9707-8_4

Khalaf, M, Z., Kadhum, M. J., Tareq, A. M., Almbhel, A., \& Khalaf, H. S. (2020). Effect of pollinator cultivars on some date palm yield characteristics. Plant Archives, 20, 1169-1178. https://www.researchgate.net/publication/340582857 


\section{Ali et al., / Basrah J. Agric. Sci., 34(2): 10-28, 2021}

_EFFECT_OF_POLLINATOR_CULTIVARS_ON_ SOME_DATE_PALM_YIELD_CHARACTERISTI CS

Khattab, M., El-torky, M. G., Mostafa, M. M., \& Doaa Reda, M. S. (2000). Pretreatment of gladiolus cormels to produce commercial yield: 2-Effect of replanting the produced corms on the vegetative growth; flowering and corms production. Alexandria Journal Agriculture, Research, 45, 201-219. https://www.cabdirect.org/cabdirect/abstract/200130 58816

Marshall, K. (2004). Therapeutic applications of whey protein. Alternative Medicine Review, Journal of Clinical Therapeutic, 9, 136-156. https://pubmed.ncbi.nlm.nih.gov/15253675/

Miroslav, C., \& Morse, D. (1998). Mechanism of the long - term effects of electromagnetic radiation on solutions and suspended collides. Langmuir, 14, 783-787. https://doi.org/10.1021/la970979a

Munir, M., Alhajhoj, M. R., Sallam, A. A. M., Ghazzawy, H. S., \& Al-Bahigan, A. M. (2020). Effects of indigenous and foreign pollinizers on the yield and fruit characteristics of date palm cultivar. Iraqi Journal of Agricultural Sciences, 51, 356-365. https://doi.org/10.36103/ijas.v51i1

O'kiely, P., \& O'Rordan, E. T. (1998). Quantitative and Qualitative effect of VI-AQUA activated water on the germination and growth of Lolium perenne. Z. P. M. (Europe) Ltd., Innovation center, National Technology Park, Limerick, 21pp. https://www.coursehero.com/file/43393006/VIAQUA-VITALIZED-WATERpdf/

Rambabu, K|., Bharath, G., Hai, A., Banat, F., Hasan, S. W., Taher, H., \& Zaid, H. F. M. (2020). Nutritional quality and physico-chemical characteristics of selected date fruit varieties of the United Arab
Emirates. Processes Journal, 8, 256. https://doi.org/10.3390/pr8030256.

Regalado, C., Pérez-Pérez, C., Lara-Cortés, E., \& GarcíaAlmendarez, B. (2006). Whey protein based edible food packaging films and Coatings. 237-261. In Guevara-González, R. G., \& Torres-Pacheco, I. (Eds.). Advances in Agriculture and Food Biotechnology. 347pp. https://www.semanticscholar.org/paper/Wheyprotein-based-edible-food-packaging-films-andRegalado-P\%C3\%A9rezP\%C3\%A9rez/e767afdcbe659e951f42b28c52f34092 c527f477

Saruwatari, M. (1980). Magnetic Seed Treating Device. US. Patent, No. 4188751. 121pp. https://patentimages.storage.googleapis.com/5e/74/a a/3ce611410c0c19/US4188751.pdf

Walzem, R. L., Dillard, C. J., \& German, J. B. (2002). Whey components. Millennia of evolution create functionalities for mammalian nutrition: What we know and what we may be overlooking. Critical Reviews in Food Science and Nutrition, 42, 353-375. https://doi.org/10.1080/10408690290825574

Wang, X., Zhou, Y., Wang, L., Feng, X., Yang, K., Ma, J., Zhenshun Li, Z., Lan Wang, L., \& Sun, W. (2020). Gel properties of myofibrillar proteins heated at different heating rates under a lowfrequency magnetic field. Food Chemistry, 321, 15. https://doi.org/10.1016/j.foodchem.2020.126728

Young, I. C., \& S. Lee, S. (2005). Reduction in the surface tension of water due to physical water treatment for fouling control in heat exchanged. International communications in Heat and Mass Transfer, 321, 1-9. https://doi.org/10.1016/j.icheatmasstransfer.2004.03. 019 
Ali et al., / Basrah J. Agric. Sci., 34(2): 10-28, 2021

دراسة تأثير الثرش الحامضي و الانزيمي الممغنط في الصفات النوعية والاتتاجية لأصناف من نخيل التمر

حيدر ابراهيم علي1 وعبدالكريم محمد عبد² ووفاء حسج خصاف3

1قسم علوم الاغذيةـ كلية الزر اعة، جامعة البصرة، العراق2 قسم البستنة، كلية الزر اعة، جامعة البصرة، العراق

3ركز ابحاث النخيل، جامعة البصرة، العراق

المستخلص: أجريت هذه الدراسة في احد البساتين الأهلية في قضاء أبي الخصيب التابع لمحافظة البصرة، خلال موسمي النمو

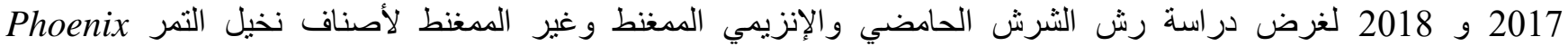
dactylifera L.

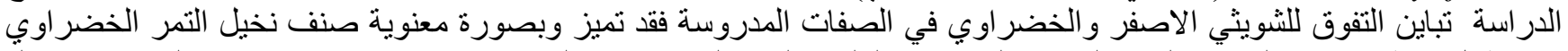

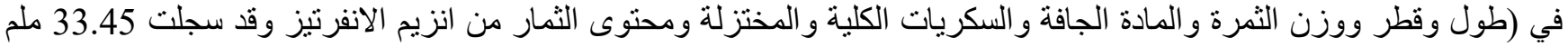

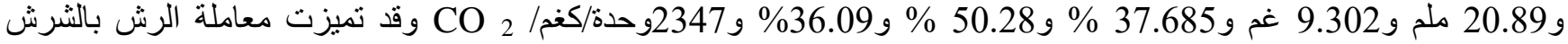

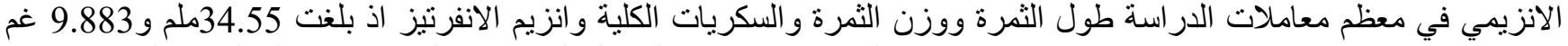

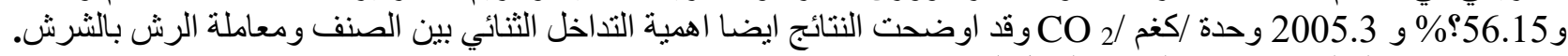
كلمات مفتاحيه: نظلة التمر ، بروتينات الثرش، المجال المغناطيسي. 